\title{
Strategi Pemahaman Tentang Protokol Kesehatan di Masa Pandemi Covid-19 di Desa Menanti, Kelurahan Tlogowaru, Kecamatan Kedungkandang, Kota Malang
}

\author{
Strategy for Understanding Health Protocols during the Covid-19 Pandemic in Menanti \\ Village, Tlogowaru Sub-District, Kedungkandang District, Malang City \\ ${ }^{1 *}$ Hidayati Karamina, ${ }^{2)}$ Ariani Trisna Murti, ${ }^{3)}$ Elita Mega Selvia Wijaya \\ ${ }^{1}$ Program Studi Agroteknologi, Fakultas Pertanian \\ ${ }^{2}$ Program Studi Peternakan, Fakultas Pertanian \\ ${ }^{3}$ Program Studi Matematika, Fakultas Ilmu Pendidikan \\ Universitas Tribhuwana Tunggadewi \\ Jl. Tlaga Warna, Tlogomas \\ *email: hidayatikaramina@yahoo.com
}

DOI:

10.30595/jppm.v5i1.9378

Histori Artikel:

Diajukan:

04/01/2021

Diterima:

$10 / 01 / 2022$

Diterbitkan:

$18 / 02 / 2022$

\begin{abstract}
ABSTRAK
Tujuan kegiatan pengabdian masyarakat ini yaitu untuk memberikan pengetahuan serta kemampuan dalam menghadapi penyebaran COVID-19. Metode yang digunakan dalam kegiatan pengabdian masyarakat ini yaitu dengan melakukan penyuluhan yang diikuti oleh perwakilan warga sejumlah 24 orang yang dibagi menjadi 2 kelompok kecil. Adapun materi penyuluhan ini yaitu mengajak warga tentang melakukan protokol kesehatan, menerapkan perilaku pentingnya hidup bersih, mampu menerapkan social distancing, menggunakan masker, serta diakhiri dengan melakukan kegiatan pembagian masker gratis untuk perwakilan warga desa menanti sejumlah 24 orang tersebut. Hal ini merupakan langkah pencegahan penyebaran virus COVID-19 Hasil dari kegiatan pengabdian kemasyarakatan ini yaitu masyarakat khususnya warga desa menanti memiliki informasi beberapa pengetahuan tentang wabah virus COVID-19 dan mampu mengantisipasi serta meminimalisir penyebaran virus COVID-19. Dengan pembagian masker secara gratis ini juga dapat meringankan beban warga untuk membeli masker yang mungkin warga sedang kesulitan pendapatan. Bagaimanapun ditengah suasana pandemi seperti ini diharapkan warga bisa lebih waspada tetap menjaga protokol kesehatan serta tidak panik menghadapi COVID-19 ini.
\end{abstract}

Kata kunci: Virus COVID-19; Pandemi; Pencegahan

\begin{abstract}
The purpose of this community service activity is to provide knowledge and skills in dealing with the spread of COVID-19. The method used in this community service activity is by conducting counseling which is attended by 24 citizen representatives divided into 2 small groups. The material for this counseling is to invite residents to carry out health protocols, to apply the importance of clean living behavior, to be able to apply social distancing, to use masks, and to end with distributing free masks to representatives of villagers waiting for the 24 people. This is a step to prevent the spread of the COVID-19 virus. The result of this community service activity is that the community, especially villagers, is waiting to have some information about the Covid-19 virus outbreak and be able to anticipate and minimize the spread of the COVID-19 virus. This free distribution of masks can also ease the burden on residents to buy masks, which may be difficult for residents to earn. However, in the midst of a pandemic like this, it is hoped that residents can be more vigilant while maintaining health protocols and not panicking in facing COVID-19.
\end{abstract}


Hidayati Karamina, Ariani Trisna Murti, Elita Mega Selvia Wijaya

Strategi Pemahaman Tentang Protokol Kesehatan di Masa Pandemi Covid-19 di Desa Menanti, Kelurahan

Tlogowaru, Kecamatan Kedungkandang, Kota Malang

Keywords: Covid-19 Diseases; Pandemic; Prevention

\section{PENDAHULUAN}

Pada tanggal 12 Februari 2020, WHO resmi menetapkan novel corona virus merupakan penyakit yang dapat terjangkit di tubuh manusia. Corona virus disease atau yang disebut dengan COVID-19 juga termasuk dalam keluarga besar SARS-COV2 (WHO, 2020). Sampai saat ini terdapat lebih dari 65 negara yang telah tertular virus COVID-19 (PDPI, 2020). Penyakit ini dapat bertransimisi atau dapat diartikan dapat menular dari manusia ke manusia (Relman, 2020). Virus ini dapat menyebar dengan sangat cepat dan masih dilakukan penelitian lebih lanjut terkait dengan perkembangan COVID-19. Kasus kematian pertama kali pasien yang terinfeksi COVID-19 yaitu adalah lelaki umur 61 tahun dengan penyakit bawaan yaitu tumor dan kelainan liver (The straits Time, 2020).

Corona virus mampu bertransmisi dan masuk kedalam saluran pernafasan dari saluran nafas inilah virus ini melanjutkan siklus hidupnya, sehingga terjadi infeksi akut disaluran pernafasan. Setelah virus tersebut menginfeksi badan seseorang maka dilanjutkan ke sel gastrointestinal setelah proses penyembuhan. Masa inkubasi virus ini sampai muncul sekitar kurang lebih 3 - 7 hari (PDPI, 2020).

Pada awal tahun 2020 yaitu bulan Januari, COVID-19 pertama kali masuk di Indonesia. Hal ini ditegaskan oleh pakar Epidemologi Universitas Indonesia. Hal ini juga diperkuat dengan data WHO bahwa per tanggal 2 Maret 2020 jumlah penderita posiitif COVID-19 sebanyak 90.308 (Yuliana, 2020). Sehingga total pasien yang dinyatakan sembuh dan negative COVID-19 ada 105.198 orang (Thomas, 2020). Perkembangan COVID-19 yang tidak dapat dikendalikan ini tidak menutup kemungkinan akan mengalami penyebaran yang cukup drastis. Langkah cepat yang dapat dilakukan oleh masyarakat yaitu dengan cara memulai menjaga diri sendiri dan keluarga kita dengan menerapkan protokol kesehatan yang baik dan benar. Langkah cepat tanggap ini dapat dilakukan dengan cara yang sederhana dimana kita dapat melakukan sosialisasi pemahaman ke masyarakat/warga di lingkungan sekitar kita sendiri. Diharapkan dengan adanya pemahaman terhadap protocol kesehatan yang baik dan benar dilingkungan keluarga kemudian disebarkan dan diterapkan di lingkungan masyarakat/warga sekitar maka akan meminimalisir penularan virus COVID19.

Daerah Desa Menanti, Kelurahan Tlogowaru, Kecamatan Kedungkandang merupakan daerah dengan kalangan keluarga kelas menengah kebawah. Lokasi ini merupakan kompleks desa wisata yang dibina oleh Lembaga Kesejahteraan Sosial Insan sejahtera yang sangat kurang tentang pemahaman penularan COVID-19. Berdasarkan hasil survey pada warga desa menanti ini diketahui bahwa belum dipahaminya secara utuh mengenai wabah COVID-19, apa itu COVID-19, bagaimana cara penyebaran COVID-19, bagaimana cara menanggulangi penyebaran COVID-19. Hasil ini yang melandasi untuk dilakukan kegiatan pengabdian masyarakat dalam bentuk strategi pemahaman tentang protocol kesehatan di tengah wabah virus corona untuk memberikan pengetahuan kepada warga desa menanti dalam menghadapi pandemi COVID-19 ini.

\section{METODE}

1. Tahapan persiapan

Tahapan persipan pertama yaitu melakukan kunjungan ke lokasi pengabdian masyarakat di Desa Menanti, Kelurahan Tlogowaru, Kecamatan Kedungkandang. Tahapan kedua yaitu menyiapkan beberapa kebutuhan kegiatan pengabdian masyarakat yang dipergunakan saat pelaksanaan pengabdian kemasyarakatan berlangsung. 
Hidayati Karamina, Ariani Trisna Murti, Elita Mega Selvia Wijaya

Strategi Pemahaman Tentang Protokol Kesehatan di Masa Pandemi Covid-19 di Desa Menanti, Kelurahan

Tlogowaru, Kecamatan Kedungkandang, Kota Malang

2. Tahapan pelaksanaan

Metode pelaksanaan pengabdian masyarakat ini langkah pertama yaitu dengan membagi kedua grup kecil maksimal 12 orang. Kemudian setelah dibagi dalam 2 grup pemateri selaku pengabdi memberi materi tentang sosialisasi mengenai COVID-19 dan cara mengatasi penyebaran COVID-19. Materi berupa pemaparan melalui slide power point dan banner protokol kesehatan COVID19 yang menarik sehingga bisa di tempel di tempat lalu lalang warga harapannya warga dapat membaca sewaktu-waktu dan selalu diingat oleh warga. Kemudian kegiatan setelah melakukan pemaparan selama 30 menit pengabdi melakukan pembagian masker kepada perwakilan 24 orang agar masyarakat paham tentang pentingnya penggunaan masker dan menjaga jarak aman.

\section{HASIL DAN PEMBAHASAN}

Desa menanti Kelurahan Tlogowaru, Kecamatan Kedungkandang, Kota Malang merupakan desa yang disulap untuk desa wisata adapun jumlah yang mengikuti kegiatan penyuluhan ini adalan perwakilan warga sejumlah 24 orang. Hasil dari kegiatan ini terbagi menjadi 2 kegiatan yaitu yang pertama adalah tahapan persiapan dimana pada tahapan persiapan ini pengabdi bertujuan untuk melihat kondisi sosial warga desa menanti yang ratarata tidak peka terhadap lingkungan sekitar.

Pada parameter klasifikasi pendidikan rata-rata pendidikan warga yaitu lulusan SD. Sedangkan pada aspek ekonomi serta pekerjaan dari warga setempat rata-rata pekerjaan warga disana adalah pekerja buruh lepas harian untuk laki-laki dan untuk perempuan ibu rumah tangga dari sini sudah bisa disimpulkan bahwa penghasilan warga tidak menentu.

Setelah itu tahapan selanjutnya yaitu adalah tahapan pelaksanaan dimana pada tahapan pelaksanaan ini pengabdi melakukan sosialisasi secara kelompok-kelompok kecil dimana materi pengabdian kali ini garis besarnya adalah tentang pengetahuan bagaimana cara penanggulangan penyebaran dari COVID-19. Pendekatan sosialisasi perkelompok kecil kali ini dipilih dikarenakan pentingnya melakukan pemahaman secara menyeluruh dengan cara pemberian pengetahuan kepada seluruh warga desa menanti baik anggota keluarga bapak, ibu, anak karena semua peran dalam keluarga berdampak pada lingkungan.

Pemahaman yang dimulai dari diri sendiri mampu menciptakan perubahan bagi dirinya dan lingkungannya menjadi lebih baik. Usaha sosialisasi ini dilakukan tidak lain karena tahapan antisipasi yang dilakukan digarda terdepan yaitu adalan dilakukan di lingkungan yang paling kecil yaitu di lingkungan keluarga. Diri sendiri sehat, keluarga sehat mampu menerapkan protocol kesehatan yang baik akan berdampat besar pada lingkungan sekitar wilayah desa menanti itu sendiri.

Adapun cara pencegahan penularan virus corona dapat dilakukan dengan beberapa cara, yaitu dimulai dengan menjaga pola hidup sehat, selalu melakukan kegiatan rajin dalam bercuci tangan dengan air mengalir dan ditambahkan dengan aplikasi sabun setelah dari luar rumah atau setelah memegang benda apapun, dilarang keras untuk menyentuh beberapa area wajah seperti bagian mulut, mata dan hidung. Tutup mulut menggunakan tissue kering jika batuk atau bersin jangan dengan tangan kosong untuk menutup batuk maupun bersin, gunakan masker saat berpergian keluar rumah dimana masker tersebut adalah masker yang sesuai dengan anjuran pemerintah.

Pencegahan tersebut bisa dilakukan mulai dari diri sendiri, jika badan dirasa kurang sehat seperti merasakan sedikit demam, ada gejalan batuk kering, ditambah dengan adanya pilek dan diare, segera hubungi tenaga medis terdekat untuk dilakukan penanganan lebih lanjut. Selain menggunakan masker cara pencegahan virus corona juga dapat dengan cara menjaga jarak aman kurang lebih 2 meter, membawa peralatan makan sendiri bila makan diluar rumah, jika dirasa kurang nyaman gunakanlah baju lengan panjang untuk meminimalisir bersenggolan dengan tubuh orang lain di tempat umum, biasakan minimal 
Hidayati Karamina, Ariani Trisna Murti, Elita Mega Selvia Wijaya

Strategi Pemahaman Tentang Protokol Kesehatan di Masa Pandemi Covid-19 di Desa Menanti, Kelurahan

Tlogowaru, Kecamatan Kedungkandang, Kota Malang

membawa handsanitizer pribadi untuk dibawa kemanapun, tissue basah/kering, dan peralatan ibadah milik pribadi.

Adapun 2 banner yang dibagikan di warga yaitu tentang pencegahan virus COVID19 dan bagaimana cara adaptasi di era new normal (kebiasaan baru). Kedua banner tersebut dibuat berdasarkan dari sumber Kementerian Kesehatan Republik Indonesia, sehingga informasi yang disampaikan sesuai dengan protokol kesehatan yang digalakkan oleh pemerintah. Pemasangan banner diletakkan ditempat yang dapat dilihat dengan jelas oleh warga dan yang sering dilalui oleh warga setempat. Pada pelaksanaannya beberapa pertanyaan yang diajukan oleh warga setempat karena banyak warga yang masih belum memahami bahayanya penyebaran virus COVID-19. Tetapi setelah dilakukan sosialisasi terkait COVID-19 banyak warga yang sudah paham bahayanya virus ini bagi dirinya sendiri dan orang lain.

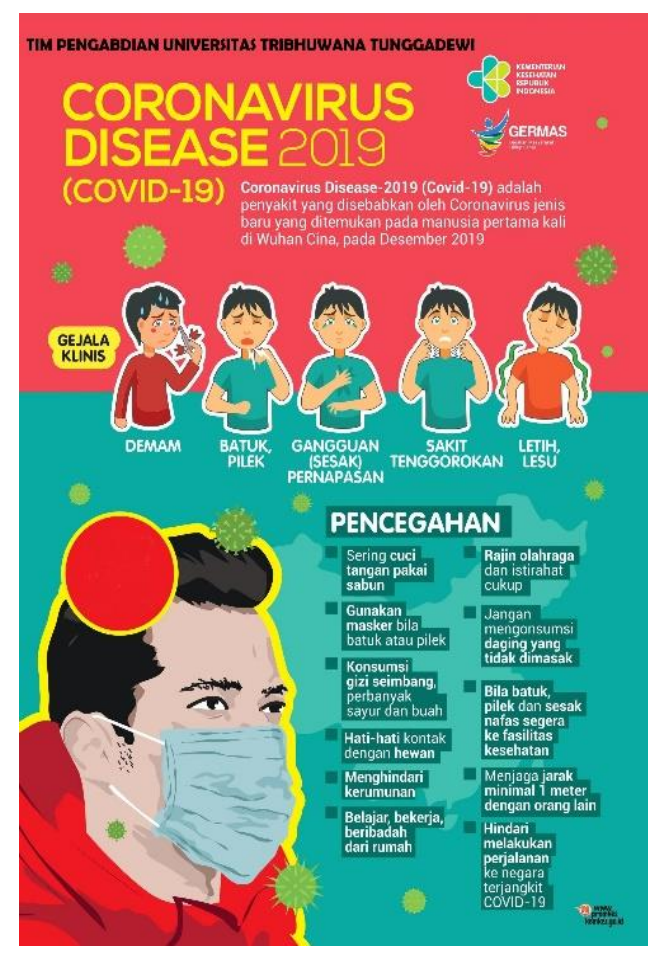

Gambar 1. Banner yang dipasang di pemukiman warga sebelah kanan

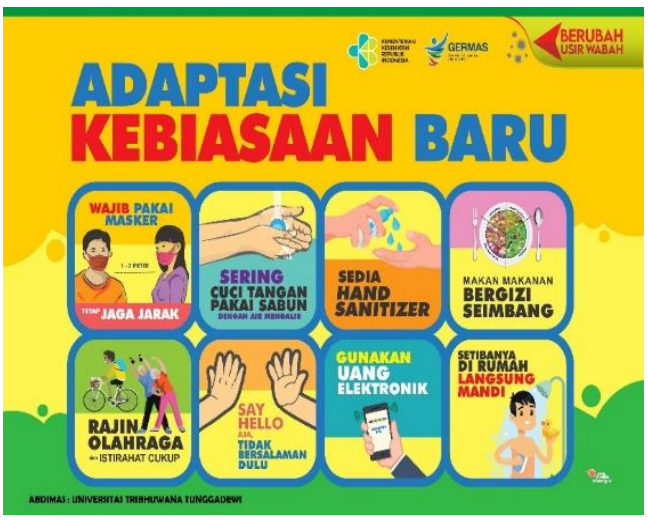

Gambar 2. Banner yang dipasang di pemukiman warga sebelah kiri

Tahap kedua dari pelaksanaan kegiatan abdimas ini yaitu adalah memberikan pengetahuan bagaimana cara menekan penyebaran virus COVID-19 secara langsung. Dimana kegiatan pengabdian yang kedua ini yaitu dengan membagikan masker gratis kepada warga setempat. Adapun pembagian masker ini diberikan ke semua warga baik bapak ibu dan anak-anak. Hal ini mengedukasi bahwa pemakaian masker tidak hanya dilakukan oleh orang dewasa saja tetapi melainkan anak-anak juga harus menggunakan masker saat kita keluar rumah.

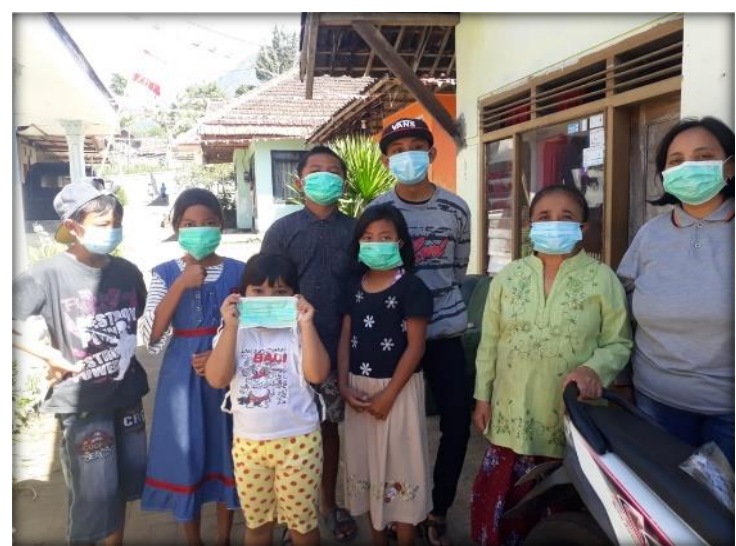

Gambar 3. Pembagian masker ke warga 
Hidayati Karamina, Ariani Trisna Murti, Elita Mega Selvia Wijaya

Strategi Pemahaman Tentang Protokol Kesehatan di Masa Pandemi Covid-19 di Desa Menanti, Kelurahan

Tlogowaru, Kecamatan Kedungkandang, Kota Malang

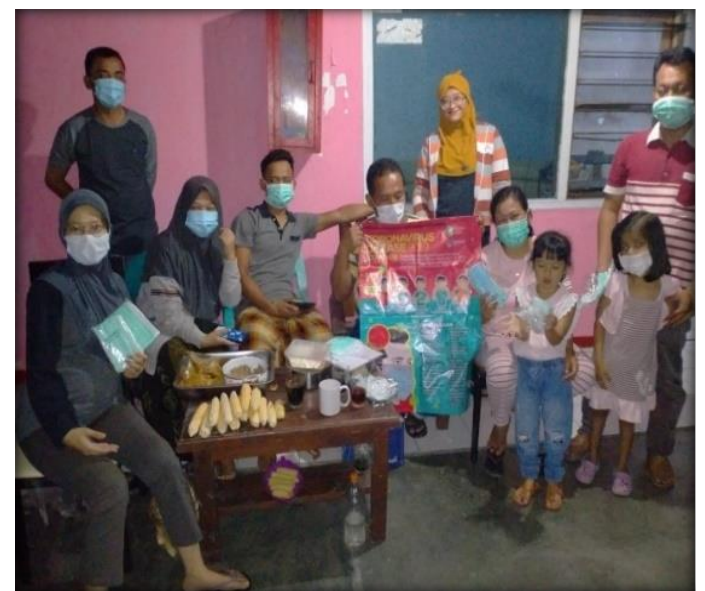

Gambar 4. Pembagian masker ke warga

Segala usaha sosialisasi pengabdian yang telah dilaksanakan selama sosialisasi mendapatkan respon yang sangat positif dari seluruh warga desa menanti, warga senang dengan kehadiran pengabdi ke lokasi mereka karena mereka sekarang tahu bahayanya virus COVID-19 sehingga warga mampu mengantisipasi langkah-langkah pencegahan COVID-19. Hasil dari pengabdian ini tidak lain adalah untuk warga dimana pengetahuan dan kemampuan warga dalam menghadapi penyebaran virus COVID-19 sehingga warga akan lebih waspada serta warga mampu menghadapi pandemik ini dengan hati-hati.

Menurut hasil pengabdian yang dipublikasikan oleh Lubis, dkk (2020) Masyarakat Desa Cilawu belum sepenuhnya sadar akan bahaya virus corona. Di masa pandemi menjaga pola makan sehat menjadi sangat krusial. Pencegahan bisa dilakukan dengan cara melakukan physical distancing dan lebih banyak berada di dalam rumah. Namun itu tidak menjamin akan terhindar dari virus, harus dilakukan peningkatan imun. Untuk itu masyarakat juga perlu menerapkan pola makan sehat untuk menaikkan imun tubuh. Sedangkan, Bekti dkk (2020) juga mengungkapkan bahwa warga harus mengetahui pengetahuan dan mengetahui ciriciri gejala klinis Covid-19 dan mematuhi himbauan pemerintah tentang pencegahannya sehingga dapat meminilisir penyebarannya.

\section{SIMPULAN}

Berdasarkan hasil dan pembahasan yang telah dijabarkan diatas pelaksanaan pengabdian masyarakat terkait dengan strategi pelaksanaan penanggulangan COVID-19 diperoleh bahwa warga desa Menanti, Kelurahan Tlogowaru, Kecamatan Kedungkandang, Kota Malang saat ini telah mememili pengetahuan serta kemampuan dalam menanggulangi penyebaran virus COVID-19 warga lebih waspada dan lebih berhati-hati dalam menghadapi wabah virus corona, warga tetap bias beraktifitas tetapi dengan protocol kesehatan yang disarankan oleh pemerintah, memakai masker, social distancing dan meningkatkan kebersihan.

\section{UCAPAN TERIMA KASIH}

Terima kasih kami ucapkan kepada warga Desa Menanti, Kelurahan Tlogowaru, Kecamatan Kedungkandang, Kota Malang yang telah memberikan izin, bantuan fasilitas dan mendukung penuh pelaksanaan kegiatan pengabdian kepada masyarakat di Desa Menanti, sehingga kegiatan berjalan dengan baik dan lancar. Selanjutnya ucapan terima kasih kepada LPPM Universitas Tribhuwana Tunggadewi yang telah mendanai kegiatan pengabdian masyarakat ini.

\section{DAFTAR PUSTAKA}

Bekti, R. D., Suryowati, K., dan Suseno, H., P (2020). Pemberian Sosialisasi dan Bantuan Pencegahan Covid-19 bagi Warga Malangan Kota Yogyakarta Berdasarkan Analisis Tingkat Pengetahuan. Jurnal Abdimasku, Vol. 3, No. 3. Hal : 99-105

Lubis, N., Saputra, M. H., Baasith, R. I., Setiadi, S., dan Oktaviani, S (2020). Gerakan Desa Sadar Bahaya Covid 19: Pengabdian Pada Masayrakat Desa Cilawu Kabupaten Garut. Jurnal kreativitas pengabdian kepada masyarakat (PKM). Vol 3 No 2. Hal 480-494

WHO. (2020). WHO Director Generals remarks at the media briefing on 2019 
n Cov on 11 February 2020. Cited Feb

13rd 2020. Avaible on http://www.who.int/dg/speeches/detai $1 /$ who remarks at the media briefing on 2019. (Feb 12 th 2020)

Perhimpunan dokter paru Indonesia. (2020). Panduan praktik klinis : Pneumonia 2019 n- cov, PDPI, Jakarta

Relman, E. (2020). Business insider Singapore. Cited Jan 28 th 2020. Avaible on https://www.businessinsider.sg/deadl y-china-wuhan-viruspreading-humanto-human-officials-confirm-2020.

The Straits Times. (2020). China reports first death in Wuhan pneumonia outbreak [cited $2020 \mathrm{Feb}$ 12]. Available from: https://www.straitstimes.com/asia/eas t-asia/chinareports-first-death-inwuhan-pneumonia-outbreak.

Thomas. (2020). Update Corona COVID-19 di Indonesia Per 22 Agustus: Ada Tambahan 2.090 Kasus. Retrieved from Liputan 6: https://www.liputan6.com/bola/read/4 33

Yuliana. (2020). Corona virus diseases (COVID-19); Sebuah tinjauan literatur. Wellness and Healthy Magazine 